\title{
Dispersal of fungi spores by non-specialized flower-visiting birds
}

\author{
Luis P. da Silva, António Pereira Coutinho, Ruben H. Heleno, Paulo Q. Tenreiro and Jaime A. Ramos \\ L. P. da Silva (http://orcid.org/0000-0003-2358-1277) (Ifpascoals@gmail.com) and J. A. Ramos, MARE - Marine and Environmental \\ Sciences Centre, Dept of Life Sciences, Univ. of Coimbra, PT-3004-517 Coimbra, Portugal. - A. Pereira Coutinho, R. H. Heleno and LPdS, CFE - \\ Centre for Functional Ecology, Dept of Life Sciences, Univ. of Coimbra, Calçada Martim de Freitas, PT-3000-456 Coimbra, Portugal. - P. Q. \\ Tenreiro, ICNF - Inst. da Conservação da Natureza e das Florestas, Depto de Conservação da Natureza e Florestas do Centro, Divisão de Gestão \\ Operacional e Valorização, Mata Nacional do Choupal, PT-3000-611 Coimbra, Portugal.
}

\begin{abstract}
Birds are important biotic dispersers of a wide range of propagules. Fungi spores are mainly dispersed by wind. Nevertheless there are several animals known to disperse fungi spores, which might be particularly important if spores are delivered to particularly favourable sites i.e. directed dispersal. This may be especially important for fungi that require specific microsites such as flowers. We sampled birds for the presence of fungi spores and pollen grains during one year at two forest sites in central Portugal. We found that out of the 894 birds sampled, 131 individuals from 11 species carried spores from at least 6 morphological types, mainly during winter. The great majority of birds found to carry fungi spores was also found to carry pollen grains, suggesting that they were feeding on flowers which are the main origin of the spores. This co-dispersion of pollen and fungi spores suggest that the latter are not randomly dispersed on the environment, but are likely to have an increased probability of being deposited on flowers propitious to fungi development. Our results suggest that directed dispersal of fungi by flower-visiting birds might by a common and under-appreciated phenomenon with potentially important ecological, biogeographic and even economic outcomes.
\end{abstract}

Due to their ubiquity and mobility, birds are very important animal dispersal vectors for a vast array of propagules, from microorganisms as bacteria (Elfving et al. 2010) and fungi (Suthers 1985, Cafarchia et al. 2006, Belisle et al. 2014), to plants (Brochet et al. 2010, Costa et al. 2014) and even small aquatic invertebrates (Sánchez et al. 2012).

Fungi spores are mainly dispersed by wind (Aylor 2003, Viljanen-Rollinson et al. 2007) but animal dispersion may also play an important role on spore dissemination (Suthers 1985, Nagarajan and Singh 1990, Viljanen-Rollinson et al. 2007). In wind dispersal the deposition of spores is mostly random, being affected by general wind patterns regardless of the biological characteristics of the deposition microsite. Conversely, dispersal by animals is dependent on their behaviour and has the potential to be specifically directed at suitable deposition sites - directed dispersal (sensu Wenny and Levey 1998). For example, flowers are habitat for several microfungi (Brysch-Herzberg 2004, Ngugi and Scherm 2006, Herrera et al. 2010, Belisle et al. 2012). Several typical pollinators are known to inadvertently transport fungi between flowers, such as bees (Brysch-Herzberg 2004, Herrera et al. 2010), ants (de Vega and Herrera 2013) and even specialized nectarivorous vertebrates, as hummingbirds (Belisle et al. 2012, 2014) and bats (Belisle et al. 2014). While insects are likely to play an important role in a range of up to $10 \mathrm{~km}$ (Goddard et al. 2010), birds might be more relevant at larger spatial scales (Alfonzo et al. 2013), maybe even globally, as in liverworts - Bryopsida (Lewis et al. 2014). Birds might move fungi spores in their beaks and mouth parts (Belisle et al. 2012, 2014) that will be exposed to other flowers by directed dispersal. By contrast, spores attached to birds' body feathers or ingested (Warner and French 1970, Francesca et al. 2010, Valera et al. 2011), will tend to have lower probability of deposition on a favourable microenvironment.

In this study we used data from two different sites to describe the directed fungi dispersal by an European bird community without specialized nectarivorous birds. Specifically, we evaluated if generalist birds can be relevant dispersers of fungi spores, the relevance of the phenomena throughout the year and whether spore dispersal is correlated with pollen dispersal in flower feeding birds.

\section{Methods}

We sampled fungal spores and pollen loads on birds during an entire year, from June 2013 to May 2014, at two sites in Portugal: Vale Soeiro $\left(40^{\circ} 19^{\prime} \mathrm{N}, 8^{\circ} 24^{\prime} \mathrm{W}\right)$ and Antuzede $\left(40^{\circ} 16^{\prime} \mathrm{N}, 8^{\circ} 29^{\prime} \mathrm{W}\right)$. Both sites were old maritime pine Pinus pinaster plantations where old decaying trees have been mostly replaced by dense high Mediterranean scrubland dominated by strawberry tree Arbutus unedo and Portuguese oak Quercus faginea. While Vale Soeiro is surrounded by small 
agricultural land (mostly vineyards), Antuzede is adjacent to blue gum Eucalyptus globulus plantations and disturbed land dominated by the invasive silver wattle Acacia dealbata.

Sampling - birds were captured every half month (minimal interval of $8 \mathrm{~d}$ ) using Ecotone mist nets (Gdynia, Poland). From each bird a small sample of feathers $(3 / 4 \mathrm{~mm})$ around the beak was cut and stored in a sterile Eppendorf at $4^{\circ} \mathrm{C}$ until further processing. Birds were individually marked so that the same individual was not sampled twice on the same session. The samples were prepared by acetolysis (Erdtman 1960), dissolving most tissues, lipids, and debris and leaving mainly fungi spores (and other spores if present, such as Pteridophytes) and pollen grains. Each sample was mounted in glycerine jelly, in three microscope slides (approx. 80\% of the solution). All slides $(\mathrm{n}=2682)$ were scanned under a light microscope at a 400 magnification, to quantify spores and pollen. Fungal spores were classified into known spores morphotypes according to their main morphological traits: size, shape and degree of separation between cells, according to Saccardo et al. (1882).

Statistical analysis - in order to explore which variables influenced the presence of fungi spores on birds we used generalized linear models (GLM) with a binominal distribution (logit link function). We tested the effect of bird species; abundance of pollen (log number pollen grains +1 ; an indirect measure of bird-flower visitation), site and sampling period, on the probability of a bird carrying fungi spores (only presence/absence data was used due to the overdispersion of the data). The model was built by comparing the relative support of all possible candidate models (all variables and their possible interactions) using Akaike's information criterion (AIC). Candidate models were built using all variables and their possible interactions. An average model was calculated, using the models with $\triangle \mathrm{AIC}<2$, and the selection probability of each variable was estimated as a measure of its relative importance in the model (Burnham and Anderson 2002). All statistical analyses were carried with package MuMIn (Barton 2014) in R ver. 3.1.3 (R Core Team).

Data available from the Dryad Digital Repository: $<$ http://dx.doi.org/10.5061/dryad.2b65b > (da Silva et al. 2015).

\section{Results}

We sampled 894 birds of 34 species, of which 131 individuals of 11 species transported fungi spores, while 229 individuals of 23 species transported pollen (Table 1, Supplementary material Appendix 1, Table A1). Remarkably, the vast majority $(93.9 \%)$ of the birds with fungi also had pollen, while half $(53.7 \%)$ of the birds with pollen had fungi. Most birds with fungi spores $(71.8 \%)$ transported more than five spores $($ mean $=163 ; \min =1$; $\max =2148$ ). All birds with more than 16 pollen grains also transported spores.

Birds transported fungi spores almost all year round, with a pronounced peak in winter (Fig. 1). Six morphological spore types were identified: the most common were the Amerosporae and the Scolecosporae present in 119 and 95 birds respectively, while Didymosporae, Phragmosporae, Dictyosporae and Staurosporae, were detected less often (39,
Table 1. Number of birds sampled and prevalence of pollen and fungi spores per bird species. Only bird species with more than 10 individuals sampled are present (for the complete list see Supplementary material Appendix 1).

\begin{tabular}{lccc}
\hline Bird species & $\begin{array}{c}\text { Birds } \\
\text { sampled }\end{array}$ & $\begin{array}{c}\text { Birds with } \\
\text { pollen (\%) }\end{array}$ & $\begin{array}{c}\text { Birds with } \\
\text { fungi (\%) }\end{array}$ \\
\hline Aegithalos caudatus & 25 & $10(40.0)$ & $8(32.0)$ \\
Certhia brachydactyla & 11 & $3(27.3)$ & $0(0.0)$ \\
Cyanistes caeruleus & 16 & $4(25.0)$ & $3(18.8)$ \\
Erithacus rubecula & 215 & $29(13.5)$ & $6(2.8)$ \\
Ficedula hypoleuca & 14 & $3(21.4)$ & $0(0.0)$ \\
Fringilla coelebs & 13 & $1(7.7)$ & $0(0.0)$ \\
Garrulus glandarius & 10 & $0(0.0)$ & $0(0.0)$ \\
Parus major & 18 & $4(22.2)$ & $2(11.1)$ \\
Phylloscopus collybita & 38 & $30(78.9)$ & $27(71.1)$ \\
Phylloscopus trochilus & 27 & $6(22.2)$ & $0(0.0)$ \\
Regulus ignicapillus & 22 & $4(18.2)$ & $2(9.1)$ \\
Sylvia atricapilla & 270 & $104(38.5)$ & $76(28.1)$ \\
Sylvia borin & 10 & $3(30.0)$ & $0(0.0)$ \\
Sylvia melanocephala & 37 & $4(10.8)$ & $2(5.4)$ \\
Troglodytes troglodytes & 16 & $3(18.8)$ & $0(0.0)$ \\
Turdus merula & 74 & $7(9.5)$ & $0(0.0)$ \\
Turdus philomelos & 38 & $4(10.5)$ & $0(0.0)$ \\
Other species & 40 & $10(25.0)$ & $5(12.5)$ \\
Total & $\mathbf{8 9 4}$ & $\mathbf{2 2 9}(\mathbf{2 5 . 6 )}$ & $\mathbf{1 3 1 ( 1 4 . 7 )}$ \\
\hline
\end{tabular}

16, 2 and 1, respectively; Supplementary material Appendix 1, Table A1).

The most common and abundant fungi disperser on this study was the blackcap Sylvia atricapilla, with spores present in 76 out of 270 sampled individuals (36\%), however, chiffchaff Phylloscopus collybita was the most frequent disperser with spores on $71.1 \%$ of the 38 sampled bird species (Table 1).

The most important variable explaining the presence of fungi spores on sampled birds, according to the coefficient estimate, is the amount of pollen grains $(\mathrm{Z}=3.857, \mathrm{p}<0.001)$ (Fig. 2), followed by the sampling period $(Z=3.109$, $p=0.002)$. Neither site, bird species nor any interactions were important or significant in the averaged model (Table 2; Supplementary material Appendix 1, Table A2).

\section{Discussion}

Our results confirm that the presence of fungi around the birds' beak is highly constrained to individuals that also carry pollen and thus likely to feed on flowers. This suggests that birds feeding more often on flowers are more likely to carry fungi spores, and are also more likely to disperse them to other flowers. This confirms previous anecdotal observations of 18 birds (individuals) transporting pollen and spores (Ash et al. 1961). While we cannot completely discard some airborne spore contamination, the high number of spores found suggest that most spores likely originate from a common specific source, i.e. flowers. Airborne contamination could probably explain the very few $(n=8)$ records of fungi spores in samples with no pollen, especially since 7 of these samples have a single spore. Although our spore identification does not allow a taxonomical assignment of fungi species, most fungi that are able to grow on flowers typically have Amerosporae spores (Brysch-Herzberg 2004, 


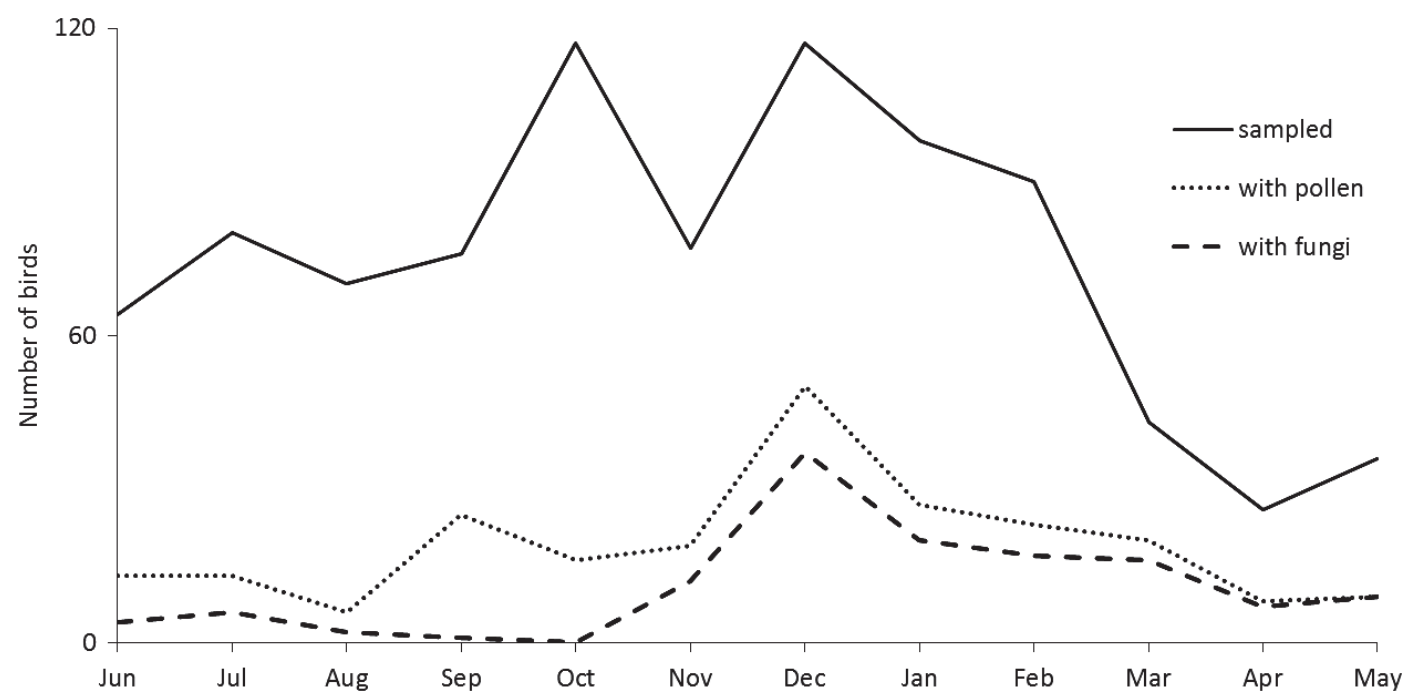

Figure 1. Monthly variation of the number of sampled birds, birds with pollen and fungi.

Ngugi and Scherm 2006, Herrera et al. 2010), which were the most common and abundant in our samples. We were only able to identify a small proportion of spores as belonging to the family Aspergillaceae. Furthermore, fungi species as Alternaria alternate, Aureobasidium pullulans, Cladosporium cladosporioides and Fusicoccum eucalypti usually found on flowers of Eucalyptus globulus (Lupo et al. 2001), which are commonly visited by birds (da Silva et al. 2014) were possibly present in our samples.

The prevalence of spores and pollen followed a similar pattern along the year except during September and October, when flowers were almost absent from the study area, and therefore a likely explanation is that spores detach from feathers earlier than pollen grains. The prevalence of fungi spores did not differ significantly between the two sampled sites. This is in line with the results from truly nectarivorous birds (hummingbirds) in Costa Rica, where the composition of fungi on the birds' beaks were not correlated with spatial distance or habitat type (Belisle et al. 2014). Our

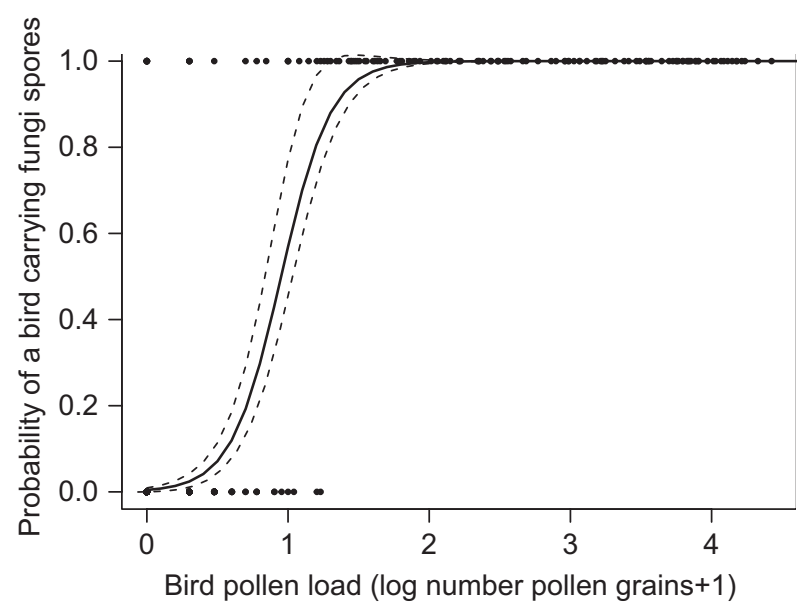

Figure 2. Predictive curve based on the averaged GLM model of the probability of a bird carrying fungi spores according to its pollen load (log number pollen grains +1$)$. Dotted lines represent the $95 \%$ confidence intervals and dots the raw data. results indicate that the dispersal of fungi spores by birds is mainly influenced by their foraging behaviour (i.e. whether they feed or not on flowers) and by the season, which influences the flower availability. Typical flower visitors, including nectar feeding insects, hummingbirds and bats, can disperse fungi spores between flowers (Brysch-Herzberg 2004, Herrera et al. 2010, Belisle et al. 2012, 2014, de Vega and Herrera 2013), sometimes quite frequently, e.g. ca $80 \%$ of the hummingbirds, from January to March, have been reported to transport fungi (Belisle et al. 2014).

European birds are known to disperse fungi between fruits (Francesca et al. 2010) and insects (Valera et al. 2011) through their faeces. Here, we show for the first time that European birds, although not specialized on flower resources, can be relevant vectors for fungi dispersion between flowers. Moreover, the quality of the dispersal for fungi spores around the beak is probably much greater than wind dispersal or than dispersal by other body parts (e.g. wings, abdomen). Birds will tend to use their beaks to forage on similar substrates, likely appropriate for fungi development. Some fungi are known to produce pseudoflowers, that mimic true flowers in shape, size, colour, scent, and nectar production (Roy 1994, Kaiser 2006). This happens for example on several crucifers species (Roy 1993, 2001), which are frequently visited by European birds (da Silva et al. 2014). While pseudoflowers are known to be highly effective attracting insects (Roy 1993) there is no information regarding its effects on birds, but since some of these pseudoflowers produce nec$\operatorname{tar}$ (Roy 1993, Roy and Widmer 1999), it is also likely that they effectively attract birds. Furthermore bird-pollinated flowers in South Africa had more spores in nectar than did flowers pollinated by other animals (de Vega et al. 2009).

The dispersion of fungi between flowers is highly relevant, as several fungi are plant pathogens that can lead to large economic losses, due to abrupt losses of fruit sets (Ngugi and Scherm 2006). Flowers, including important cultivars, are known to be important for European birds, particularly during the spring migration (da Silva et al. 2014). During their migrations, birds can easily spread spores (Lewis et al. 2014). Fungi can remain viable on the birds' feathers for over 
Table 2. Summary of the average model including the importance of each variable and the number of models were they are present. Significant values are at bold.

\begin{tabular}{|c|c|c|c|c|c|c|c|}
\hline & $\begin{array}{c}\text { Coefficient } \\
\text { estimate }\end{array}$ & $\begin{array}{l}\text { Standard } \\
\text { error (SE) }\end{array}$ & $\begin{array}{c}\text { Adjusted } \\
\text { SE }\end{array}$ & z value & $\mathrm{p}$ value & $\begin{array}{c}\text { Selection } \\
\text { probability }\end{array}$ & $\begin{array}{c}\mathrm{n} \text { models } \\
\text { present }\end{array}$ \\
\hline (Intercept) & -8.264 & 1.484 & 1.486 & 5.564 & $<0.001$ & & \\
\hline Pollen abundance & 7.514 & 1.946 & 1.949 & 3.857 & $<0.001$ & 1.00 & 4 \\
\hline Sampling period & 0.245 & 0.079 & 0.079 & 3.109 & 0.002 & 1.00 & 4 \\
\hline Pollen abundance $\times$ Sampling period & -0.199 & 0.102 & 0.102 & 1.947 & 0.051 & 0.83 & 3 \\
\hline Site & 0.156 & 1.451 & 1.452 & 0.108 & 0.914 & 0.41 & 2 \\
\hline Site $\times$ Sampling period & 0.106 & 0.099 & 0.099 & 1.070 & 0.284 & 0.16 & 1 \\
\hline
\end{tabular}

$45 \mathrm{~d}$ (Warner and French 1970), during which period birds can travel thousands of kilometres between continents (from Africa to Europe, Asia and vice-versa) and isolated islands, therefore spore dispersal by birds is likely to have biogeographic, ecological and economic repercussions.

Acknowledgements - We thank to Vanessa Mata for her suggestions on an early version of the manuscript. LPS was supported by the grant SFRH/ BD/77746/2011 of the Fundação para Ciência e Tecnologia (FCT). RH was supported by the FCT grant IF/00441/2013 and by the Marie Curie Action FP7-PEOPLE2012-CIG-321794. Bird capture and sampling was performed under the permits 'Credencial de Anilhagem' number 126/2013 and number 130/2014 from the competent national authorities (Inst. da Conservaçáo da Natureza e das Florestas - ICNF).

\section{References}

Alfonzo, A., Francesca, N., Sannino, C., Settanni, L. and Moschetti, G. 2013. Filamentous fungi transported by birds during migration across the mediterranean sea. - Curr. Microbiol. 66: 236-242.

Ash, B. J. S., Jones, P. H. and Melville, R. 1961. The contamination of birds with pollen and other substances. - Br. Birds 54: 93-100.

Aylor, D. E. 2003. Spread of plant disease on a continental scale: role of aerial dispersal of pathogens. - Ecology 84: 1989-1997.

Barton, K. 2014. MuMIn: multi-model inference. - R package ver. 1.10.0, < http://cran.r-project.org/package=MuMIn $>$.

Belisle, M., Peay, K. G. and Fukami, T. 2012. Flowers as islands: spatial distribution of nectar-inhabiting microfungi among plants of Mimulus aurantiacus, a hummingbird-pollinated shrub. - Microb. Ecol. 63: 711-718.

Belisle, M., Mendenhall, C. D., Oviedo Brenes, F. and Fukami, T. 2014. Temporal variation in fungal communities associated with tropical hummingbirds and nectarivorous bats. - Fungal Ecol. 12: 44-51.

Brochet, A. L., Guillemain, M., Fritz, H., Gauthier-Clerc, M. and Green, A. J. 2010. Plant dispersal by teal (Anas crecca) in the Camargue: duck guts are more important than their feet. - Freshwater Biol. 55: 1262-1273.

Brysch-Herzberg, M. 2004. Ecology of yeasts in plant-bumblebee mutualism in central Europe. - FEMS Microbiol. Ecol. 50: 87-100.

Burnham, K. P. and Anderson, D. R. 2002. Model selection and multimodel inference: a practical information-theoretic approach. - Springer.

Cafarchia, C., Camarda, A., Romito, D., Campolo, M., Quaglia, N. C., Tullio, D. and Otranto, D. 2006. Occurrence of yeasts in cloacae of migratory birds. - Mycopathologia 161: 229-34.
Costa, J. M., Ramos, J. A., da Silva, L. P., Timoteo, S., Araújo, P. M., Felgueiras, M. S., Rosa, A., Matos, C., Encarnação, P., Tenreiro, P. Q. and Heleno, R. H. 2014. Endozoochory largely outweighs epizoochory in migrating passerines. - J. Avian Biol. 45: 59-64.

da Silva, L. P., Ramos, J. A., Olesen, J. M., Traveset, A. and Heleno, R. H. 2014. Flower visitation by birds in Europe. - Oikos 123: 1377-1383.

da Silva, L. P., Pereira Coutinho, A., Heleno, R. H., Tenreiro, P. Q. and Ramos, J. A. 2015. Data from: Dispersal of fungi spores by non-specialized flower-visiting birds. - Dryad Digital Repository, < http://dx.doi.org/10.5061/dryad.2b65b >.

de Vega, C. and Herrera, C. M. 2013. Microorganisms transported by ants induce changes in floral nectar composition of an ant-pollinated plant. - Am. J. Bot. 100: 792-800.

de Vega, C., Herrera, C. M. and Johnson, S. D. 2009. Yeasts in floral nectar of some South African plants: quantification and associations with pollinator type and sugar concentration. - S. Afr. J. Bot. 75: 798-806.

Elfving, K., Olsen, B., Bergström, S., Waldenström, J., Lundkvist, A., Sjöstedt, A., Mejlon, H. and Nilsson, K. 2010. Dissemination of spotted fever rickettsia agents in Europe by migrating birds. - PLoS One 5: e8572.

Erdtman, G. 1960. The acetolysis method: a revised description. - Svensk Bot. Tidskr. 54: 561-564.

Francesca, N., Chiurazzi, M., Romano, R., Aponte, M., Settanni, L. and Moschetti, G. 2010. Indigenous yeast communities in the environment of "Rovello bianco" grape variety and their use in commercial white wine fermentation. - World J. Microbiol. Biotechnol. 26: 337-351.

Goddard, M. R., Anfang, N., Tang, R., Gardner, R. C. and Jun, C. 2010. A distinct population of Saccharomyces cerevisiae in New Zealand: evidence for local dispersal by insects and human-aided global dispersal in oak barrels. - Environ. Microbiol. 12: 63-73.

Herrera, C. M., Canto, A., Pozo, M. I. and Bazaga, P. 2010. Inhospitable sweetness: nectar filtering of pollinator-borne inocula leads to impoverished, phylogenetically clustered yeast communities. - Proc. Biol. Sci. 277: 747-754.

Kaiser, R. 2006. Flowers and fungi use scents to mimic each other. - Science 311: 806-807.

Lewis, L., Rozzi, R. and Goffinet, B. 2014. Direct long-distance dispersal shapes a New World amphitropical disjunction in the dispersal-limited dung moss Tetraplodon (Bryopsida: Splachnaceae). - J. Biogeogr. 41: 2385-2395.

Lupo, S., Tiscornia, S. and Bettucci, L. 2001. Endophytic fungi from flowers, capsules and seeds of Eucalyptus globulus. - Rev. Iberoam. Micol. 18: 38-41.

Nagarajan, S. and Singh, D. 1990. Long-distance dispersion of rust pathogens. - Annu. Rev. Phytopathol. 28: 139-26.

Ngugi, H. K. and Scherm, H. 2006. Biology of flower-infecting fungi. - Annu. Rev. Phytopathol. 44: 261-282.

Roy, B. A. 1993. Floral mimicry by a plant pathogen. - Nature 362: 56-58. 
Roy, B. A. 1994. The use and abuse of pollinators by fungi. - Trends Ecol. Evol. 9: 335-339.

Roy, B. A 2001. Patterns of association between crucifers and their flower-mimic pathogens: host jumps are more common than coevolution or cospeciation. - Evolution 55: 41-53.

Roy, B. A. and Widmer, A. 1999. Floral mimicry: a fascinating yet poorly understood phenomenon. - Trends Plant Sci. 4: 325-330.

Saccardo, P. A., Traverso, G. B. and Trotter, A. 1882. Sylloge fungorum omnium hucusque cognitorum. Digessit P. A. Saccardo. - Patavii, sumptibus auctoris.

Sánchez, M. I., Hortas, F., Figuerola, J. and Green, A. J. 2012. Comparing the potential for dispersal via waterbirds of a native and an invasive brine shrimp. - Freshwater Biol. 57: 1896-1903.

Supplementary material (Appendix JAV-00806 at $<$ www.avianbiology.org/appendix/jav-00806>). Appendix 1.
Suthers, H. B. 1985. Ground-feeding migratory songbirds as cellular slime mold distribution vectors. - Oecologia 65: 526-530.

Valera, F., Martín-Hernández, R. and Higes, M. 2011. Evaluation of large-scale dissemination of Nosema ceranae spores by European bee-eaters Merops apiaster. - Environ. Microbiol. Rep. 3: 47-53.

Viljanen-Rollinson, S. L. H., Parr, E. L. and Marroni, M. V. 2007. Monitoring long-distance spore dispersal by wind - a review. - N. Z. Plant Prot. 60: 291-296.

Warner, G. M. and French, D. W. 1970. Dissemination of fungi by migratory birds: survival and recovery of fungi from birds. - Can. J. Bot. 48: 907-910.

Wenny, D. G. and Levey, D. J. 1998. Directed seed dispersal by bellbirds in a tropical cloud forest. - Proc. Natl Acad. Sci. USA 95: 6204-6207. 